\title{
Effects of Oxytocin Administration on Doppler Indices of Mammary Artery in Postpartum Ewes
}

\author{
Gamze EVKURAN DAL'* \\ ${ }^{1}$ Istanbul University-Cerrahpasa, Faculty of Veterinary Medicine, Department of Obstetrics and Gynaecology, Istanbul, Turkey
}

\begin{abstract}
Oxytocin hormone, which is frequently used in order to hasten uterine involution process and to ensure milk ejection, is also effective in regulation of vascular tone. Doppler ultrasonography is a highly practical technique that allows the evaluation of blood flow characteristics of tissues and organs. In this study, it was aimed to investigate the hemodynamic changes of mammary artery caused by oxytocin administration in postpartum ewes. The study was conducted with 20 primiparous Kivircik ewes which lambed singleton. The ewes were randomly divided into oxytocin and control groups ( $\mathrm{n}=10$ for each group). A dose of $10 \mathrm{IU} / \mathrm{sheep}$ oxytocin and 1 $\mathrm{ml} /$ sheep saline solution were administered intramuscularly bid on the first 3 days postpartum to oxytocin and control groups, respectively. The pulsed Doppler ultrasonography is used to measure pulsatility and resistance indices (PI and RI, respectively) of external pudendal artery. Although oxytocin group tended to have relatively higher PI and RI values, significant differences were detected only in PI values of the first and second days postpartum $(\mathrm{p}<0.001$ and $\mathrm{p}<0.05$, respectively) between groups. It has been concluded that oxytocin administration increased the resistance of mammary artery in early postpartum ewes.
\end{abstract}

Keywords: Doppler ultrasonography, Ewes, Oxytocin

Postpartum Dönemdeki Koyunlarda Oksitosin Uygulamasının Meme Arteri Doppler İndeksleri Üzerine Etkileri

ÖZ

Doğum sonrası uterus involüsyonunu hızlandırmak ve sütün indirilmesini sağlamak amacıyla sıklıkla uygulanan oksitosin hormonu vasküler tonusun düzenlenmesinde de etkilidir. Doppler ultrasonografi, doku ve organlara ait kan akımı özelliklerinin değerlendirilebilmesine olanak sağlayan oldukça pratik bir tekniktir. Bu çalışmada postpartum dönemdeki koyunlara uygulanan oksitosin hormonunun meme kan akımında oluşturduğu hemodinamik değişikliklerin incelenmesi amaçlandı. Çalışma tekiz kuzulamış olan 20 adet primipar Kıvırcık ırkı koyun ile gerçekleştirildi. Koyunlar randomize şekilde oksitosin ve kontrol gruplarına ayrıldı (her grup için $\mathrm{n}=10$ ). Oksitosin ve kontrol gruplarına sirasiyla $10 \mathrm{IU} /$ koyun dozda oksitosin ve $1 \mathrm{ml} /$ koyun dozda serum fizyolojik doğum sonrası ilk üç gün boyunca günde 2 kez kas içi yoldan uygulandi. Puls Doppler ultrasonografi tekniği kullanılarak eksternal pudendal artere ait pulsatilite ve rezistans indeksleri (sırasıyla PI ve RI) ölçüldü. Oksitosin grubu daha yüksek PI ve RI değerlerine sahip olma eğiliminde olmasına karşın gruplar arasında anlamlı farklılık sadece birinci ve ikinci postpartum günlerin PI değerlerinde saptandı (sırasıly $\mathrm{p}<0,001$ ve $\mathrm{p}<0,05$ ). Postpartum erken dönemdeki koyunlara uygulanan oksitosin hormonunun, meme arterinin direncini arttırdığ1 sonucuna ulaşıld1.

Anahtar Kelimeler: Doppler ultrasonografi, Koyun, Oksitosin

To cite this article: Dal G.E. Effects of Oxytocin Administration on Doppler Indices of Mammary Artery in Postpartum Ewes. Kocatepe Vet J. (2020) 13(3):313-318 


\section{GİRİŞ}

Koyunlarda meme dokusunun vaskülarizasyonu eksternal iliak arterin kolu olan eksternal pudendal arter tarafindan sağlanır. Bu damarın uzantısı meme arteri olarak tanımlanır (Adam ve ark. 2016). Memenin fonksiyonel ve fizyolojik aktivitesi dokuya gerçekleşen kan akımı ile yakından ilişkilidir (Kensinger ve ark. 1983, Piccione ve ark. 2004). Ruminantlarda meme kan akım özelliklerinin incelendiği önceki y1llara ait çalısmalar invaziv yöntemleri barındırıyorken (Gorewit ve ark. 1989, Reynolds ve ark. 1968) günümüzde vasküler fonksiyon araştırmaları Doppler ultrasonografi sayesinde kolaylikla yapilabilmektedir (Piccione ve ark. 2004).

Doppler ultrasonografi, doku ve organlara ait hemodinamik özelliklerin değerlendirilebilmesine olanak sağlayan, noninvaziv, pratik ve oldukça etkin bir ön tanı aracıdır. Ses dalgalarının hareket halindeki eritrositler tarafindan farklı oranlarda geri gönderilmesi sonucu oluşan Doppler kaymas1, spektral mod veya renk kodları üzerinden monitöre aktarllır. Doppler ultrasonografi ile kan akımının haritası, yönü ve hızı belirlenebilmekte ve kan perfüzyonu hakkında bilgi edinilebilmektedir. Bir spektral teknik olan puls Doppler ultrasonografi, incelenecek doku veya organa ait çeşitli kan akım parametrelerinin kalitatif ve kantitatif değerlendirilmesine olanak sağlar (Erdoğan 2018, Meinecke-Tillmann 2017; Petridis ve ark. 2017). Bu parametrelerden pulsatilite ve rezistans indeksleri (sırasiyla PI ve RI), arteriyel kan akım hizı dalga formlarının yarı kantitatif değerlendirilmesinde sıklıkla kullanilır. PI puls dalga formu sönümlemesinin derecesini tanımlar. RI vasküler yatağın direnç göstergesidir (Meinecke-Tillmann 2017). Dokunun hemodinamiği ile yakından ilişkili olan bu indeksleri başka deyişle tanımlamak gerekirse: artan RI incelenen arterde direnç artışına ilaveten kan perfüzyonunun azaldığını gösterirken artan PI ise ölçüm alınan noktanın daha distalinde perfüzyonun azaldığını yansıtır (Ginther 2007). PI ve RI, açıdan bağımsız parametreler oluşları sebebiyle özellikle jinekolojik değerlendirmeler için önem taşır (Erdoğan 2018).

Oksitosin, hem bir nörohipofiz hormonu hem de merkezi nöromodülatör özellikte peptit yapılı bir hormondur. Oksitosin reprodüktif ve maternal davranışların gelişiminde rol oynar ve nöroendokrin yolla süt alveollerindeki myoepitel hücreleri uyararak sütün indirilmesini kolaylaştırır. (Cumbers ve ark. 2007, Landgraf ve Neumann 2004). Doğum sonras1 myometriyal kontraksiyonları arttırmak ve sütün indirilmesini hızlandırmak amacıyla da uygulanan oksitosin hormonu, myoepitelyal hücre farklılaşması, proliferasyonu ve kontraksiyonunu arttıran bir etkiye sahiptir. (Rizzo ve ark. 2012, Thibonnier ve ark. 1999).

Oksitosin bu bilinen etkilerinin yanı sıra vasküler tonusun düzenlenmesinde de etkilidir. Yapılan çalışmalarda oksitosinin farklı tür ve dokularda vazodilatasyon ya da vazokonstriksiyon gibi birbirine zit etkilere sahip olduğu görülür (Gutkowska ve ark. 2000, Petersson 2002, Petersson ve ark. 1996, Rizzo ve ark. 2012, Thibonnier ve ark. 1999, Vedernikov ve ark. 2006). İnsan vasküler endotelyal hücreleri, uterus ve meme oksitosin reseptörleri ile aynı yapıya sahip olan oksitosin reseptörleri eksprese eder. Bu endotelyal oksitosin reseptörlerinin vazodilatör bir cevap oluşturduğu rapor edilmiştir (Thibonnier ve ark. 1999). Ratlarda gerçekleştirilen bir çalş̧mada oksitosin uygulaması sonras1, kan basincinin uzun süreliğine düşük seyrettiği bildirilmiştir (Petersson ve ark. 1996). Köpeklerde intravenöz oksitosin enjeksiyonu sonrası meydana gelen vazodilatasyon, kan basincinda azalma ve kalp atım sayısinda artma ile ilişkilendirilmiştir (Nakano ve Fisher 1963). Oksitosin enjeksiyonu plazma atriyal natriüretik peptit (ANP) salınımını indükleyerek sodyum ve potasyum ekskresyonunu arttırır (Haanwickel ve ark. 1995). Oksitosinin kardiyovasküler etki mekanizmasının incelendiği bir çalışmada kalp ve büyük damar yapıları içerisinde oksitosin mRNA'ları tespit edilmiştir. Renal elektrolit ekskresyonundaki artı̧ıı vasopressinden bağımsız meydana geldiği; oksitosinin etkisiyle lokal olarak üretilen ANP'nin damar basincinın azalmasına sebep olabileceği bildirilmiştir (Gutkowska ve ark. 2000). Bahsedilen vazodilatör etkilerin aksini belirten çalışmalar da mevcuttur. Ratlarda oksitosine ait vazokonstriktif etkinin bölgesel duyarlılık gösterdiği bulunmuştur. Oksitosin uterin arter üzerinde kuvvetli konstrüksiyona sebep olurken bu etki femoral arterde ve aortada giderek azalmış, karotid arterlerde ise bulunmamıştır (Vedernikov ve ark. 2006). Oksitosinin vazokonstriktör ya da vazodilatör etkilerinin seksüel siklus dönemine veya uygulama dozuna göre farklillk arz edebileceği bildirilmiştir. Birbirinden farklı olan bu etkiler oksitosin reseptörlerinin hem endotelyal hem vasküler düz kas hücrelerinde bulunmasindan kaynaklanır (Petersson 2002, Prosser ve ark. 1996).

Çiftlik hayvanlarında meme kan akımının incelendiği çeşitli araştırmalar mevcuttur. Dişi kuzularda beslenmenin meme bezi gelişimi üzerine etkisi (Dantas ve ark. 2017), gebelik toksemisinin laktogeneziste meydana getirdiği değişiklikler (Barbagianni ve ark. 2015), emziren ve makinalı sağım uygulanan koyunlarda meme kan akımı (Piccione ve ark. 2004), koyunlarda meme involüsyonu süreci (Petridis ve ark. 2014), mastitisli keçilerde meme kan akımı (Santos ve ark. 2015), ineklerde meme veni kan akımı ile California Mastitis Test (CMT) skorlar1 arasındaki ilişki (Rişvanlı ve ark. 2018) ve yine ineklerde oksitosin uygulamasinin meme veni hemodinamiği üzerine etkisi (Rizzo ve ark. 2012) puls 
Doppler ultrasonografi ile incelenmiştir. Koyunlarda ise günlük oksitosin enjeksiyonunun süt verimi ve laktasyon uzunluğunda meydana getirdiği değişiklikler (Zamiri ve ark. 2001) araştırılmış olmakla birlikte meme kan akımı üzerine etkisini değerlendiren bir çalışmaya rastlanmamıştır. Bu çalışmada koyunlarda doğum sonrası uygulanan oksitosinin eksternal pudendal arter PI ve RI parametreleri üzerindeki etkisinin incelenmesi amaçlanmıştır.

\section{MATERYAL VE METOT}

Çalışmada klinik olarak sağlıklı olduğu bilinen primipar 20 adet Kıv1rcik 1rk1 koyun kullanıldı.

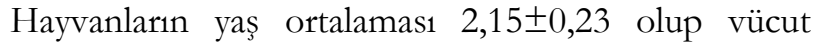
kondüsyon skoru literatür bilgiye uyumlu şekilde 3,125 $\pm 0,32 / 5$ olarak belirlendi (Russel ve ark. 1969). Tüm koyunların normal yolla, müdahalesiz şekilde tek kuzu yavruladığı ve yavru zarlarını doğumu izleyen ilk 6 saat içerisinde attığ1 görüldü. Çalışma materyali ağılda kuzuları ile birlikte barındırıldı, çalışma süresince yavrularını emzirdi ve klinik mastitis bulgusuna rastlanmadi. Koyunlar Hayvan Besleme ve Beslenme Hastalıkları Anabilim Dalı tarafindan gereksinimleri doğrultusunda hazırlanan rasyon ile beslendi. Doğum sonrası koyunlara yiyebilecekleri kadar kaliteli kuru çayır otu ve hayvan başına 0,5kg/gün koyun süt yemi (\%18,72 ham protein, 2493 $\mathrm{Mcal} / \mathrm{kg}$ metabolik enerji) verildi. Su ve yalama taşına ad libitum erişim sağlandı. Tanımlanan tüm klinik uygulamalar İstanbul Üniversitesi-Cerrahpaşa Veteriner Fakültesi Birim Etik Kurulu tarafindan onaylanmıştır (rapor no: 2019/27).

Koyunlar randomize şekilde oksitosin ve kontrol gruplarına ayrıldı. Oksitosin grubuna $(n=10)$ doğum sonrası ilk 3 gün boyunca 12 saat ara ile 10 İÜ/koyun dozda kas içi oksitosin hormonu (Oksitosin, Vetaş, Türkiye) uygulandi. Kontrol grubuna ise $(n=10)$ çalışma grubu ile eş zamanlı olarak $1 \mathrm{ml}$ / koyun dozda kas içi \%0,09 $\mathrm{NaCl}$ solüsyonu enjekte edildi. Ultrasonografik muayeneler doğum sonras1 ilk 3 gün boyunca günde bir kez, oksitosin ya da plasebo uygulamasından sonraki 10. dk'da gerçekleştirildi.

Ultrasonografik muayeneler ayakta zaptedilerek, minimum stres düzeyinde gerçekleştirildi. Meme arterine ait hemodinamik ölçümler, eş zamanlı B-mod ultrasonografi cihazının (Esaote Pie Medical MyLab Five Vet, Esaote Pie Medical, Ittalya) puls Doppler tekniği ile gerçekleştirildi (6,6 $\mathrm{MHz}$ mikrokonveks prob, $60 \mathrm{~mm}$ derinlik). Memeyi besleyen eksternal pudendal arteri belirlemek için prob meme lobunun kaudaline, meme-abdomen sinirina konumlandirildı. Ardindan renkli Doppler modu ile pudendal arter görüntülendi. Optimal renk akımı sağlandığında puls Doppler ile spektral mod aktifleştirildi ve örnekleme yapıldı (Şekil 1). İnsonasyon açısının 60\% den küçük olmasina özen gösterildi. Örnekleme sirasinda hayvanlarin sakin ve hareketsiz olmasina dikkat edilerek, en az üç ardış1k artefaktsız trase sonrası PI, RI değerleri otomatik olarak kaydedildi. İşlem sırasıyla her iki meme lobu için tekrarland, grupların karşılaştırılmasında iki ölçümün ortalaması kullanıldı.

\section{İstatistiksel Analizler}

İstatistiksel analizler için SPSS 20.0 paket veri programı kullanıld1. Oksitosin ve kontrol gruplarına ait PI ve RI ortalama değerleri arasında farklılık olup olmadığ1 Student $\mathrm{t}$ testi ile incelendi. İstatistiksel farklılık için $\mathrm{p}<0,05$ anlamlı kabul edildi.

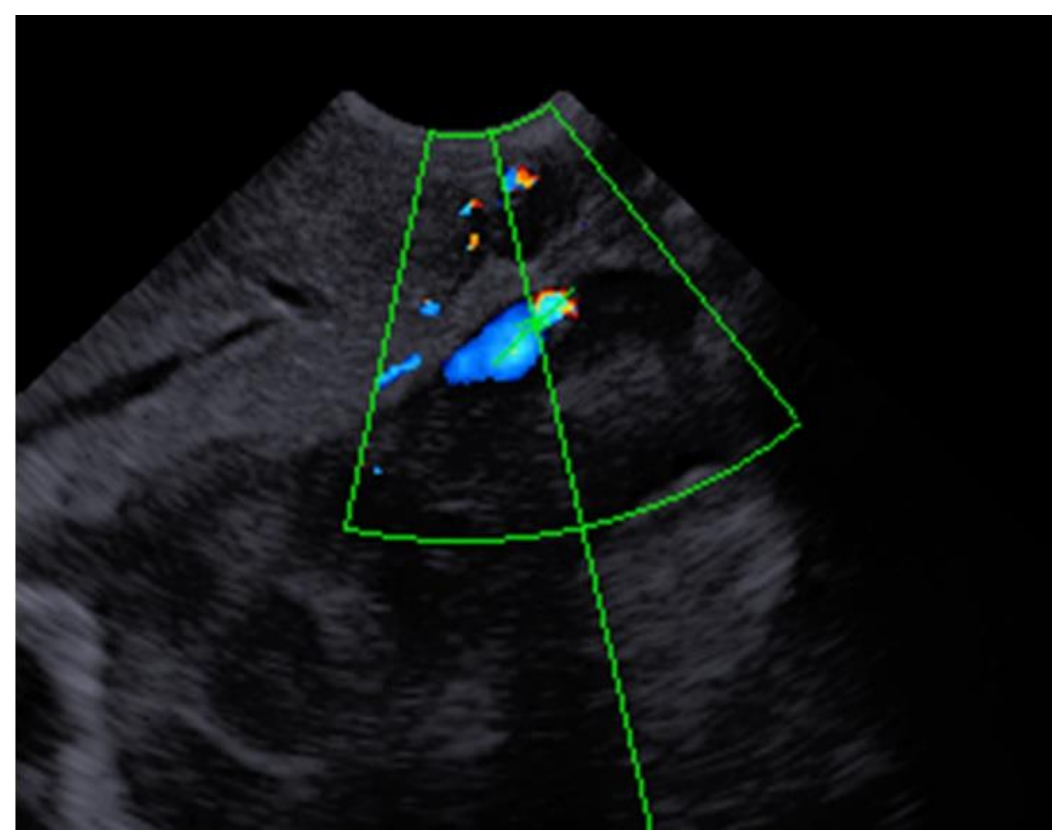

Şekil 1. Eksternal pudendal arterin puls Doppler ultrasonografi ile görüntüsü

Figure 1. Image of external pudendal artery by pulse Doppler ultrasonography 


\section{BULGULAR}

Meme arterine ait hemodinamik parametreler incelendiğinde oksitosin uygulanan grubun kontrol grubundan matematiksel olarak daha yüksek PI ve RI değerlerine sahip olduğu görüldü. Gruplar arasındaki PI değerleri ortalaması fark1, postpartum birinci ve ikinci günde anlamlı bulundu (sirasiyla $\mathrm{p}<0,001$ ve $\mathrm{p}<0,05)$. Oksitosin uygulanan grupta en yüksek PI değeri $(1,61 \pm 0,05)$ çalıșmanın ilk gününde saptandı. Kontrol grubunda ise bu indeks, çalışma ilerledikçe matematiksel bir artış gösterdi (Şekil 2).

Günlük ortalama RI değerleri incelendiğinde gruplar arasında istatistiksel farklılık saptanmadı (Şekil 3). Bununla birlikte RI değerleri her iki grupta da artan bir

gösterdi.

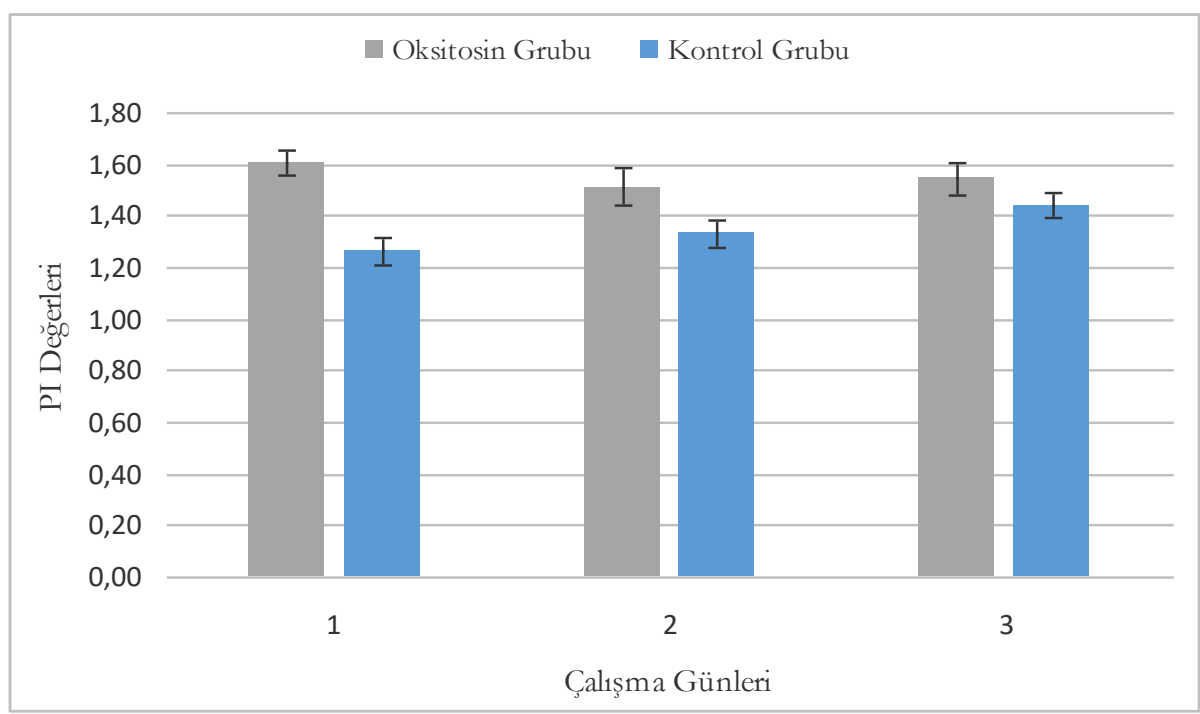

Şekil 2. Oksitosin ve kontrol gruplarına ait ortalama PI değerleri

Figure 2. Mean PI values of oxytocin and control groups

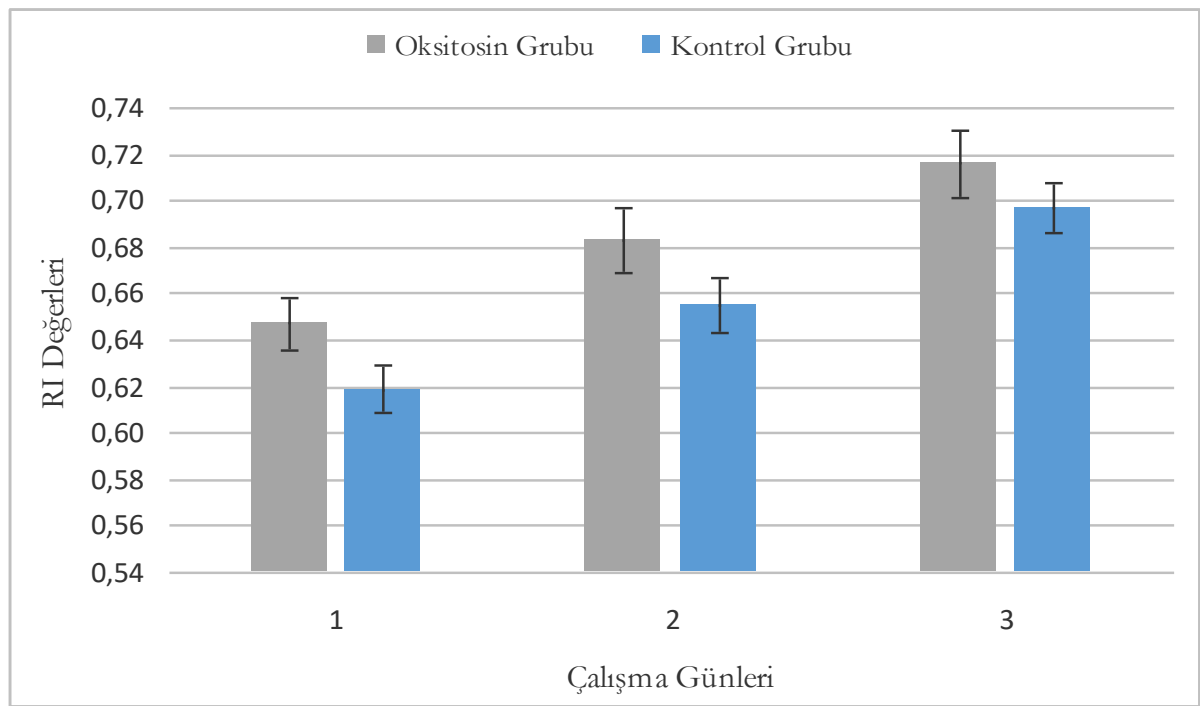

Şekil 3. Oksitosin ve kontrol grubuna ait ortalama RI değerleri

Figure 3. Mean RI values of oxytocin and control groups 


\section{TARTIŞMA ve SONUÇ}

Sütçü işletmelerde memeden sütün indirilmesini sağlamada, mastititis olgularının tanı ve sağaltımında oksitosin hormunu siklıkla uygulanir (Macuhova ve ark. 2004). Koyunlarda da laktasyon sürecini süt verimi yönünden yönetmek için oksitosin uygulaması yapilmakla birlikte (Zamiri ve ark. 2001) doğum sonrası yavru zarlarının atılımını kolaylaştırmak ve involüsyon sürecini hızlandırmak amacıyla da oksitosine başvurulur (Kuru ve ark. 2016). Uterus ve meme dokusunun yanı sira endotelyal doku ve merkezi sinir sistemi dokusunda da reseptörlere sahip olan oksitosinin seksüel ve maternal davranışlanı uyarıc1 etkilerine ilaveten kardiyovasküler fonksiyonları olduğu da belirlenmiştir (Gutkowska ve ark. 2000, Thibonnier ve ark. 1999). Bu kardiyovasküler etki, incelenen damar yapısına göre vazodilatasyon ya da vazokonstriksiyon ile sonuçlanır (Petersson 2002, Prosser ve ark. 1996, Rizzo ve ark. 2012). Sunulan çalışmada elde edilen indeks verileri, oksitosinin meme arterinde direnç arttırıcı etkisini ortaya koydu. Çalışmada eksternal pudendal artere ait çap verileri değerlendirilmemiş olmakla birlikte damar direncindeki artışı vazokonstriktif etkiyi işaret ettiği düşünülmektedir. Oksitosin uygulanan grupta gözlenen istatistiksel öneme sahip PI artışı (Şekil 2), oksitosinin meme damar1 direncinde ve basincinda artışa, distal perfüzyonda ise azalmaya sebep olduğunu tanımlamaktadır.

Koyun meme dokusuna ait kan akım özelliklerinin incelendiği araştırma sayısı kısıtlıdır. Dişi kuzularda beslenmenin meme bezi gelişimi üzerine etkisinin incelendiği bir çalışmada gruplar arasında vücut gelişimi farklilıkları oluşmasına rağmen meme arterine ait PI ve RI değerleri benzer bulunmuştur (Dantas ve ark. 2017). Gebeliğin özellikle son dönemlerinden itibaren laktogenezis için gelişen meme dokusunu besleyen eksternal pudendal arter genişler ve dokuya kan akımı artar. Gelişen meme dokusunda meydana gelen hemodinamik değişiklikler çeşitli Doppler ultrasonografi indeksleri ve parametreleri ile takip edilebilir (Barbagianni ve ark. 2015). Makineli sağım uygulanan koyunlarda meme arterine ait sistolik ve diyastolik akım hızlarının sağım sonrası arttığ1 tespit edilmiş; bu durum meme içi basıncın sağıma bağlı olarak düşmesi ile ilişkilendirilmiştir. Emziren koyunlarda memenin kuzular tarafindan devamlı uyarılmasının bir sonucu olarak sabah ve akşam ölçümleri arasında farklılık oluşmadığı bildirilmiştir. Kuru dönemde ise kan akım hız1, meme bezinin inaktif olmasından ötürü daha düşük gözlenmiştir (Piccione ve ark. 2004). Sunulan çalışmada koyunların kuzuları ile birlikte barındırılarak emzirmenin kısıtlanmaması, meme içinde biriken süt miktarında bireysel farkliliklar oluşturabilmekle birlikte çalışmanın tekiz kuzu yavrulamıs primipar hayvanlarda ve postpartum ilk 3 gün içinde gerçekleştirilmesi ile birörneklik sağlanmaya çalışıldı. Her iki grupta da çalışma ilerledikçe artan RI değerleri (Şekil 3), meme arteri direncinde artış ve akım hızında azalmayı işaret etti. Bu durum kuzuların sık aralıklarla memeyi uyarmasi neticesinde memenin makineli sağımda meydana geldiği gibi tam boşalmadan tekrar süt üretimine devam etmesi ve dolayısıyla meme içi basıncın artması ile açılanabilir. Meme bezinin involüsyon sürecinde ise PI ve RI değerlerinin arttığ1 bildirilmiştir. Ancak bu durum boşaltılmayan sütün meme içinde birikerek meme içi basınc1 artmasından ziyade, süt sekresyonundaki azalmaya bağlı olarak dokunun kanlanma ihtiyacının azalmasının bir sonucu olduğuna dikkat çekilmiştir (Petridis ve ark. 2014). Laktasyondaki ineklere uygulanan oksitosinin meme veninde vazodilatasyona sebep olduğu bildirilmiştir. Ancak oksitosinin incelenen damar yapisina göre farklı etkileri olabileceği ve hormonun myoepitelyal hücreler üzerindeki etkisi neticesinde artan arteriyel kan akımının bir sonucu olarak da venöz vazodilatasyon şekillenebileceğine dikkat çekilmiştir (Rizzo ve ark. 2012). Sunulan çalışmada emzirmeye bağlı olarak süt üretiminin devam etmesine ilaveten uygulanan oksitosinin süt alveollerinde oluşturduğu kontraktil etkiler neticesinde meme dokusuna ait kan akımında değişikliklerin gözlenebileceği sonucuna varılmıştır. Ayrıca oksitosinin damar endotel ve kas hücreleri üzerindeki olası lokal vazokonstriktif etkisi, oksitosin grubunda gözlenen direnç artışı ile ilişkilendirilebilir. Oksitosinin damar tonusu üzerindeki bu karşıt etkilerinin çalışmalar arasındaki metot farklılığından kaynaklanmış olabileceği düşünülmektedir. Elde edilecek verilerin çalısmanın gerçekleştirildiği dönem (seksüel siklus, gebelik, laktasyon, meme involüsyonu), hayvanların yavruları ile ya da ayr1 barındırılması, emzirme, sağım, hastalık durumu, incelenen damar tipi gibi faktörlerden etkileneceği göz önünde bulundurulmalıdır.

Doppler ultrasonografi ile ruminantlarda meme hastalıkları ve gebelik toksemisi gibi olgularda belirgin değişimler gözlenmiştir (Barbagianni ve ark. 2015, Rişvanlı ve ark. 2018, Santos ve ark. 2015). Sunulan çalışmada sağlıklı koyunlara ait Doppler indekslerinin, meme kan akımını etkileyebilecek çeşitli hastalıkların ayırıcı tanısında yol gösterici olacağı düşünülebilir.

Yapılan bu çalş̧ma ile doğum sonrası oksitosin uygulamasinın, koyunların meme arteri direncini arttırdığı sonucuna ulaşıldı. Oksitosinin koyunlarda meme arteri tonusu üzerindeki etkilerini ortaya koymaya yönelik yeni çalş̧malara ihtiyaç duyulmaktadır.

Conflict of Interest: The authors declare that they have no conflict of interest. 


\section{KAYNAKLAR}

Adam ZA, Ragab GA, Awaad AS, Tawfiek MG, Abdel Maksoud MKM. Anatomical and radiographical studies on the arterial supply of the udder in goat and their surgical importance. BJBAS. 2016; 5(3): 291-298.

Barbagianni MS, Gouletsou PG, Valasi I, Petridis IG, Giannenas I, Fthenakis GC. Ultrasonographic findings in the ovine udder during lactogenesis in healthy ewes or ewes with pregnancy toxaemia. J Dairy Res. 2015; 82(3): 293-303.

Cumbers MR, Chung ST, Wakerley JB. A neuromodulatory role for oxytocin within the supramammillary nucleus. Neuropeptides. 2007; 41(4): 217-226.

Dantas A, Siqueira ER, Fernandes S, Oba E, Machado VMV, Castilho AM, Sartori MMP, Santos RV. Mammary artery Doppler ultrasonography of Brazilian Bergamasca dairy ewe lambs under the influence of two different feding plans. Pesq Vet Bras. 2017; 37(2): 179182.

Erdogan G. Veteriner jinekolojide Doppler ultrasonografi kullanım alanları. Turkiye Klinikleri J Vet Sci Obstet Gynecol-Special Topics. 2018; 4(1): 43-49.

Ginther OJ. Producing Spectral Graphs, In: Ultrasonic Imaging and Animal Reproduction: Color-Doppler Ultrasonography Book 4, Ed; Ginther OJ, Equiservices Publishing, Wisconsin, USA. 2007; pp. 61-86.

Gorewit RC, Aromando MC, Bristol DG. Measuring bovine mammary gland blood flow using a transit time ultrasonic flow probe. J Dairy Sci. 1989; 72(7): 1918-1928.

Gutkowska J, Jankowski M, Mukaddam-Daher S, McCann SM. Oxytocin is a cardiovascular hormone. Braz J Med Biol Res. 2000; 33(6): 625-633.

Haanwickel MA, Elias LK, Favaretto ALV, Gutkowska J, McCann SM. Oxytocin mediates atrial natriuretic peptide release and natriuresis after volume expansion in the rat. Proc Natl Acad Sci USA. 1995; 92(17): 79027906.

Kensinger MH, Collier RJ, Wilcox CJ, Caton D. Variability of resting mammary blood flow in nonlactating Holstein cows. J Dairy Sci. 1983; 66(8): 1742-1746.

Kuru M, Mülazımoglu SB, Kaya D. Koyun ve keçilerde güç doğum. Turkiye Klinikleri J Vet Sci Obstet GynecolSpecial Topics. 2016; 2(1): 74-77.

Landgraf R, Neumann ID. Vasopressin and oxytocin release within the brain: a dynamic concept of multiple and variable modes of neuropeptide communication. Front Neuroendocrin. 2004; 25(3-4): 150-176.

Macuhova J, Tancin V, Bruckmaler RM. Effects of oxytocin administration on oxytocin release and milk ejection. J Dairy Sci. 2004; 87(5): 1236-1244.

Meinecke-Tillmann S. Basics of ultrasonographic examination in sheep. Small Rumin Res. 2017; 152: 10-21.

Nakano J, Fisher RD. Studies on the cardiovascular effects of synthetic oxytocin. J Pharmacol Exp Ther. 1963; 142(2): 206-214.
Petersson M. Cardiovascular effects of oxytocin. Prog Brain Res. 2002; 139: 281-288.

Petersson M, Alster P, Lundeberg T, Uvnas-Moberg K. Oxytocin causes a long-term decrease of blood pressure in female and male rats. Physiol Behav. 1996; 60(5): 1311 1315.

Petridis IG, Barbagianni MS, Ioannidi KS, Samaras E, Fthenakis GC, Vloumidi EI. Doppler ultraonographic examination in sheep. Small Rumin Res. 2017; 152: 22-32.

Petridis IG, Gouletsou PG, Barbagianni MS, Amiridis GS, Brozos C, Valasi I, Fthenakis GC. Ultrasonographic findings in the ovine udder during involution. J Dairy Res. 2014; 81(3): 288-296.

Piccione G, Arcigli A, Assenza A, Percipalle M, Coala G. Pulsed wave-Doppler ultrasonographic evaluation of the mammary blood flow in the ewe. Acta Vet Brno. 2004; 73(1): 23-27.

Prosser CG, Davis SR, Farr VC, Lacasse P. Regulation of blood flow in the mammary microvasculature. J Dairy Sci. 1996; 79(7): 1184-1197.

Reynolds M, Linzell JL, Rasmussen F. Comparison of four methods for measuring mammary blood flow in conscious goats. Am J Physiol. 1968; 214(6): 1415-1424.

Risvanli A, Dogan H, Saat N, Seker I. Relationship between pulsed wave Doppler ultrasonographic features of milk veins and CMT scores in Simmental cows. Ankara Üniv Vet Fak Derg. 2018; 65(1): 69-72.

Rizzo A, Mutinati M, Minoia G, Spedicato M, Pantaleo M, Sciorsci RL. The impact of oxytocin on the hemodynamic features of the milk vein in dairy cows: a color Doppler investigation. Res Vet Sci. 2012; 93(2): 983-988.

Russel AJ, Doney FJM, Gunn RG. Subjective assessment of fat in live sheep. J Agric Sci. 1969; 72(3): 451-454.

Santos VJC, Simplicio K, Sanchez D, Coutinho I, Teixeira P, Barros F, Almeida V, Rodrigues I, Bartlewski P, Oliveira M, Feliciano M, Vicente W. B-mode and Doppler sonography of the mammary glands in dairy goats for mastitis diagnosis. Reprod Dom Anim. 2015; 50(2): 251-255.

Thibonnier M, Conarty DM, Preston JA, Plesnicher CL, Dweik RA, Erzurum SC. Human vascular endothelial cells Express oxytocin receptors. Endocrinology. 1999; 140(3): 1301-1309.

Vedernikov YP, Betancourt A, Wentz MJ, Saade GR, Garfield RE. Adaption to pregnancy leads to attenuated rat uterine artery smooth muscle sensitivity to oxytocin. Am J Obstet Gynecol. 2006; 194(1): 252-260.

Zamiri MJ, Qotbi A, Izadifard J. Effect of daily oxytocin injection on milk yield and lactation length in sheep. Small Rum Res. 2001; 40(2): 179-185. 